\author{
Anna Szychta \\ Uniwersytet Łódzki \\ e-mail: anna.szychta@uni.lodz.pl \\ ORCID: 0000-0001-8465-0542
}

\title{
SPECJALIŚCI DO SPRAW RACHUNKOWOŚCI ZARZĄDCZEJ W PRZEDSIĘBIORSTWACH MAŁYCH, ŚREDNICH I DUŻYCH W ŚWIETLE WYNIKÓW BADANIA EMPIRYCZNEGO W POLSCE
}

\section{MANAGEMENT ACCOUNTANTS IN SMALL, MEDIUM AND LARGE ENTERPRISES \\ IN THE LIGHT OF EMPIRICAL RESEARCH IN POLAND}

DOI: $10.15611 /$ pn.2019.11.19

JEL Classification: M40, M41, M49

\begin{abstract}
Streszczenie: Cele artykułu stanowią ustalenie hierarchii ważności zadań specjalistów do spraw rachunkowości zarządczej, określenie znaczenia wskazanych czynników determinujących te zadania oraz wymagań kompetencyjnych wobec tych specjalistów w badanych przedsiębiorstwach w Polsce w zależności od wielkości przedsiębiorstwa. Cel ten osiągnięto dzięki analizie i prezentacji danych pozyskanych w badaniu ankietowym dotyczącym ponad 100 przedsiębiorstw działających w Polsce. Interpretacji wyników analizy dokonano w przekroju trzech grup przedsiębiorstw podzielonych według kryterium wielkości zatrudnienia (małe, średnie i duże). Wyniki badania pokazują, że specjaliści w dziedzinie rachunkowości zarządczej pracują głównie w działach controllingu, wykonują podobne zadania, koncentrując się na kontroli kosztów oraz ustalaniu i ocenie wyników przedsiębiorstw bez względu na ich wielkość. Badanie ankietowe wykazało nieliczne różnice w analizowanych aspektach.
\end{abstract}

Słowa kluczowe: specjaliści do spraw rachunkowości zarządczej, zadania, umiejętności, wielkość przedsiębiorstwa, Polska.

Summary: The aim of the article is to set the hierarchy of the tasks of management accountants and to recognise importance of indicated factors determining these tasks, and to point out competency requirements of the management accountants in the surveyed enterprises in Poland, depending on the size of the enterprise. This goal was achieved based on the analysis and presentation of data obtained in the survey on over 100 enterprises operating in Poland. The interpretation of the survey findings was carried out in cross-section of three groups of enterprises divided according to the criterion of employment for small, medium and large. The findings show that management accountants work mainly in the controlling departments, 
perform similar tasks, focusing on cost control and determining and evaluating the performance of enterprises regardless of their size. The empirical study revealed few differences in the examined aspects of these specialists in small, medium and large enterprises.

Keywords: management accountants, tasks, skills, company size, Poland.

\section{Wstęp}

Zawód management accountant, który ukształtował się w Stanach Zjednoczonych i Wielkiej Brytanii, a następnie w innych krajach anglojęzycznych w drugiej połowie $\mathrm{XX}$ wieku, $\mathrm{z}$ jednej strony podlega przemianom dotyczącym roli odgrywanej w podmiotach gospodarczych, z drugiej zaś nabiera charakteru profesji globalnej ze względu na rozszerzanie zakresu podmiotowego zastosowania rachunkowości zarządczej (RZ) o przedsiębiorstwa w krajach rozwijających się i będących w fazie transformacji ustrojowej (zob. np. [Anderson, Lanen 1999; Hopper i in. 2009; Ngoc Phi Anh i in. 2011; O'Connor i in. 2004]). Odpowiednikiem tej profesji w Polsce jest zawód specjalisty do spraw rachunkowości zarządczej (w dalszej części artykuły określany jest on jako specjalista ds. RZ), który w praktyce zaczął funkcjonować od lat 90. XX wieku, a formalnie został wyodrębniony w 2010 r. w Klasyfikacji zawodów i specjalności na potrzeby rynku pracy oraz zakresu jej stosowania ${ }^{1}$.

Specjalista ds. RZ (kod 241106) wchodzi w skład elementarnej grupy zawodowej 2411 - specjaliści do spraw księgowości i rachunkowości. W ramach tej grupy wymieniono również zawód specjalisty do spraw controllingu (kod 241102). Wydaje się, że wyszczególnienie tych dwóch profesji wynikało z chęci jednoczesnego uwzględnienia dwóch koncepcji odnoszących się do pracowników wspierających menedżerów w procesach zarządzania: angloamerykańskiej (management accountant) i niemieckiej (Controller) (zob. szerzej [Szychta 2011; 2014, s. 792]). Włączenie tych dwóch zawodów do grupy zawodowej 2411 odzwierciedla także tendencję obserwowaną w praktyce gospodarczej w Polsce od początku transformacji systemowej, wyrażającą się tworzeniem stanowisk pracy controllera albo specjalisty w zakresie RZ. Potwierdzają to badania empiryczne (np. [Goliszewski 2002; Szychta 2007, s. 236-237; 2018; Zarzycka 2016, s. 198, 254]), jak również wyniki badania ankietowego prezentowanego $\mathrm{w}$ niniejszym artykule.

Cele artykułu stanowią ustalenie hierarchii ważności zadań specjalistów w zakresie rachunkowości zarządczej, a także określenie znaczenia wskazanych czynników determinujących wykonywanie tych zadań oraz wymagań kompetencyjnych stawianych specjalistom ds. RZ w małych, średnich i dużych przedsiębiorstwach w Polsce objętych badaniem empirycznym. Osiągnięcie celu nastąpi dzięki udzieleniu odpowiedzi na następujące pytania badawcze:

${ }^{1}$ Obecnie klasyfikację zawodów w Polsce reguluje Rozporządzenie Ministra Pracy i Polityki Społecznej z dnia 7 sierpnia 2014 r., Dz.U. z dnia 25 stycznia 2018 r., poz. 227. 
1. W jakich działach w badanych przedsiębiorstwach są wykonywane zadania z zakresu RZ?

2. Jaka jest hierarchia ważności określonych zadań specjalistów ds. RZ w przedsiębiorstwach małych, średnich i dużych?

3. Jakie czynniki spośród wskazanych w kwestionariuszu ankiety w największym stopniu wpływają na zadania specjalistów ds. RZ w badanych przedsiębiorstwach w zależności od ich wielkości?

4. Czy w opinii respondentów występują różnice w ocenie wiedzy i umiejętności, jakimi powinni charakteryzować się praktycy RZ w przedsiębiorstwach $\mathrm{w}$ zależności od ich wielkości?

Motywacją autorki do podjęcia się analizy przedmiotowego zagadnienia była chęć zmniejszenia luki w wiedzy o zróżnicowaniu bądź podobieństwie zadań i wymagań fachowych stawianych specjalistom ds. RZ/controllingu w Polsce w zależności od wielkości przedsiębiorstwa. Mimo przeprowadzanych dotychczas analiz empirycznych dotyczących statusu tych specjalistów w naszym kraju (np. Dynowska 2011; Nowak 2013; Pietrzak, Wnuk-Pel 2015; Sobańska 2010b; Sobańska, Wnuk 2000; Szychta 2005, 2007, 2018; Wnuk-Pel, Kawczyńska 2016; Zarzycka 2016]), niewiele wiadomo, czy i w jakim stopniu występują różnice w omawianych kwestiach w podmiotach małych, średnich i dużych.

Dane niezbędne do udzielenia odpowiedzi na przytoczone pytania pozyskano w badaniu ankietowym ze 102 funkcjonujących w Polsce przedsiębiorstw o różnej wielkości. Wyniki badania prezentowane $\mathrm{w}$ artykule nie mogą być uogólnione na wszystkie przedsiębiorstwa w kraju, ponieważ próba badawcza nie była losowa. Ankietę wypełnili respondenci z przedsiębiorstw, które wyraziły zgodę na udział w badaniu. Jego rezultaty umożliwiają rozpoznanie znaczenia zadań i ocenę stopnia ważności kompetencji zawodowych wymaganych od specjalistów w zakresie RZ w przedsiębiorstwach o różnej wielkości, mierzonej liczbą zatrudnionych. Artykuł uzupełnia dotychczasowy stan wiedzy o statusie i roli tych specjalistów w warunkach polskiej gospodarki rynkowej.

W artykule najpierw dokonano syntezy opinii autorów na podstawie przeglądu wybranych zagranicznych pozycji literatury przedmiotu i polskich publikacji, które przedstawiają wyniki badań empirycznych dotyczących praktyków RZ. Następnie przedstawiono metodykę badania własnego i jego wyniki w nawiązaniu do sformułowanych pytań badawczych. Punkt ostatni prezentowanego tekstu zawiera wnioski.

\section{Rola specjalistów do spraw rachunkowości zarządezej w ujęciach postulatywnym i empirycznym}

Od lat 90. XX wieku międzynarodowe organizacje rachunkowości i autorytety naukowe propagują pogląd, że rolą specjalisty ds. RZ jest nie tylko dostarczanie danych finansowych i operacyjnych na potrzeby decyzyjne kierowników podmiotów gospodarczych, lecz także współudział w procesie zarządzania (np. [AICPA, CIMA 
2015; Birkett 1995; CIMA 2009; IFAC 1998; IMA 2008; Kaplan 1995]). Specjaliści ci mają być partnerami biznesowymi menedżerów, ich doradcami w procesach zarządzania. Aby tak było, muszą mieć wiedzę nie tylko z zakresu RZ, lecz również z podstaw zarządzania, finansów i prawa oraz umiejętności przewidywania, oceny ryzyka i myślenia w kategoriach strategicznych.

Wyzwania stawiane współczesnym specjalistom ds. RZ syntetycznie wyrażono w definicji rachunkowości zarządczej sformułowanej przez ekspertów amerykańskiego instytutu IMA (Institute of Management Accountants), wskazującej, że: „rachunkowość zarządcza jest działalnością zawodową (zawodem) polegającą na współdziałaniu w podejmowaniu decyzji kierowniczych, opracowywaniu systemów planowania i zarządzania wynikami oraz dostarczaniu wiedzy fachowej w zakresie sprawozdawczości finansowej i kontroli (sterowania) w celu wsparcia kierownictwa przy formułowaniu i wdrażaniu strategii organizacji” [IMA 2008, s. 1]. Jak stwierdzono w Globalnych zasadach rachunkowości zarzadczej, opracowanych przez AICPA i CIMA [2015, s. 14 i 23], rola tych specjalistów się rozszerza, ponieważ zapewniają oni dogłębne zrozumienie problemów biznesowych przez menedżerów, a ich wpływ na organizacje staje się coraz większy. Następuje zatem przesunięcie akcentu $\mathrm{z}$ technicznych umiejętności tych specjalistów na umiejętności biznesowe. Jak podkreślają Sobańska i Kabalski [2014, s. 21], wysokie umiejętności z zakresu finansów i rachunkowości są warunkiem koniecznym, lecz niewystarczającym. Niezbędne jest, aby specjalistów ds. RZ charakteryzowały takie cechy, jak: świadomość strategiczna, zrozumienie biznesu, umiejętności wpływania na innych i przywódcze, komunikatywność, umiejętność prezentacji i budowania zespołów [CIMA 2009, s. 25].

Postulowana zmiana roli specjalistów ds. RZ oznacza, że we współczesnych przedsiębiorstwach powinno następować odchodzenie przez nich od działań według tradycyjnego modelu biernego dostarczyciela danych finansowych dla kierowników (bean counter, score-keeper - liczykrupy) na rzecz modelu wewnętrznego konsultanta biznesowego (internal business consultant) albo finansowego partnera biznesowego (finance business partner). Wyniki badań empirycznych przeprowadzanych w ostatnich trzech dekadach w krajach zachodnich potwierdzają zmiany w zdaniach i sposobie pracy specjalistów ds. RZ, choć nie są one jednolite i nie przebiegają w jednakowym tempie w różnych krajach (np. [Burns, Vaivio 2001; Byrne, Pierce 2007; Grandlund, Lukka 1998b; Kaplan 1995; Keating, Ansari 1997; Lambert, Sponem 2012; Rieg 2018; Selto, Widener 2004; Scapens i in. 2003]). Proces zmiany roli w praktyce nie jest też tak powszechny, jak wynikałoby z obrazu kształtowanego w publikacjach takich organizacji, jak IMA [2008], CIMA [2009], AICPA i CIMA [2015].

Badania ankietowe przeprowadzone w Stanach Zjednoczonych w 1993 r. wykazały występowanie dwóch typów praktyków RZ, nazwanych policjantami przedsiębiorstwa i adwokatami gospodarczymi [Keating, Ansari 1997, s. 6-9]. Zaliczeni do pierwszej grupy zajmowali się głównie budżetowaniem, analizą odchyleń i precyzyjną sprawozdawczością finansową, koncentrowali się na administrowaniu 
i nadzorowaniu wykonania obowiązujących przepisów. Adwokaci gospodarczy zaś mieli szerszą wiedzę z zakresu ekonomiki przedsiębiorstwa, zajmowali się różnego typu analizami ekonomicznymi, monitorowaniem wykonania budżetów operacyjnych i kapitałowych oraz służyli pomocą zespołom zadaniowym i kierownikom na różnych szczeblach zarządzania $\mathrm{w}$ formułowaniu lub wykonaniu strategii przedsiębiorstwa. Policjanci przedsiębiorstwa działali zgodnie z modelem been counter, a adwokaci gospodarczy funkcjonowali jako wewnętrzni konsultanci biznesowi. W raporcie badawczym z przytoczonych badań wyrażono nadzieję, że dominująca do lat 90. XX wieku w amerykańskich przedsiębiorstwach rola praktyka RZ jako policjanta zostanie zastąpiona przez pożądaną rolę adwokata gospodarczego (zob. szerzej [Szychta 2007, s. 153-155]).

Badania empiryczne przeprowadzone w Wielkiej Brytanii na przełomie XX i XXI wieku potwierdzały wzrost znaczenia w praktyce umiejętności analitycznych specjalistów ds. RZ i społecznych aspektów ich roli (np. [Burns i in. 2003; Scapens $i$ in. 2003]). Irlandzcy badacze Byrne i Pierce [2007] wyszczególnili przesłanki, cechy i konsekwencje towarzyszące rolom odgrywanym przez specjalistów ds. RZ na podstawie pogłębionych wywiadów z 18 menedżerami finansowymi i 18 menedżerami operacyjnymi. Wyniki ich analiz dostarczyły dowodów na obszerną kombinację zmiennych związanych z tymi rolami oraz pokazały dużą liczbę niejasności, uwarunkowań i konfliktów, które mogą dotyczyć roli partnera biznesowego. Z kolei Lambert i Sponem [2012] wyróżnili, na podstawie badania w formie 73 wywiadów przeprowadzanych w 10 bardzo dużych, wielonarodowych spółkach, cztery różne style pracy działu RZ (odrębność, zabezpieczanie, partnerstwo, wszechstronność) i wyjaśnili, że każdy styl może być związany z jedną główną rolą specjalistów ds. RZ. Są nimi: odrębna kontrola działania kierowników, socjalizacja menedżerów, ułatwianie podejmowania decyzji i centralizacja władzy. Badanie to uwidoczniło, że koncepcja specjalisty ds. RZ jako partnera biznesowego nie jest tak powszechna w praktyce, nawet w wielkich spółkach, tak jak można wnioskować z literatury przedmiotu.

Dotychczasowe liczne publikacje zagraniczne nie tworzą spójnego obrazu współczesnych praktyków RZ, co jest skutkiem wpływu na ich zadania i postawy różnorodnych czynników. W myśl teorii uwarunkowań sytuacyjnych w literaturze rozpatrywano oddziaływania m.in. takich czynników, jak: kultura narodowa, konkurencyjność otoczenia, zmiany w otoczeniu przedsiębiorstwa, oczekiwania menedżerów, rozwój technologii, struktura organizacyjna i fizyczna lokalizacja przedsiębiorstw, wprowadzenie innowacji w dziedzinie RZ, cechy osobowe praktyków RZ (zob. [Byrne, Pierce 2007, s. 473]). Mogą to być czynniki pogrupowane jako zewnętrzne, wewnętrzne i indywidualne, jak to uczynili Byrne i Pierce [2007, s. 488], albo jako ekonomiczne i instytucjonalne w myśl klasyfikacji sił przedstawionej przez Grandlunda i Lukkę [1998a], które oddziałują na globalną homogenizację praktyk RZ.

Wyniki badań empirycznych odnoszące się do roli managemet accountants i jej zmiany interpretowano z różnych perspektyw teoretycznych, a zwłaszcza teorii uwa- 
runkowań sytuacyjnych, teorii instytucjonalnej, teorii ról w przedsiębiorstwie, teorii strukturacji A. Gidensa oraz w powiązaniu z kontrolą zarządczą (zob. np. Burns i in. 2003; Byrne, Pierce 2007, s. 471-472; Otley 2016; Zarzycka 2016 s. 32-47]).

W Polsce problematyka zadań, cech i roli specjalistów ds. RZ i controllingu dopiero od kilkunastu lat jest podejmowana i stopniowo objaśniana w artykułach i rozdziałach publikacji (np. [Dynowska 2011; Goliszewski 2002; Král i in. 2017; Nowak 2013, 2014; Sobańska 2010b; Sobańska, Kabalski 2014; Sobańska, Wnuk 2000; Szychta 2005; 2007; 2011; 2014; 2018; Zarzycka 2012; 2017]), a ostatnio także bardziej kompleksowo i szczegółowo w formie monografii [Wnuk-Pel, Kawczyńska 2016; Zarzycka 2016]. Publikacje te obrazują zadania i cechy tych specjalistów w przedsiębiorstwach funkcjonujących w Polsce, stawiane im wymogi kompetencyjne, stosowane przez nich metody z zakresu operacyjnej i strategicznej RZ oraz czynniki warunkujące zastosowanie tych metod i zmiany zachodzące w tych aspektach. Podejmowana w nich problematyka jest prezentowana na tle koncepcji funkcji pełnionych przez managemet accountants uznawanych za modelowe w rozwiniętych krajach świata, a także na podstawie wybranych wyników badań w krajach zachodnich. Na przykład zdaniem Zarzyckiej [2016; 2017] wyniki przeprowadzonego przez nią badania polegającego na analizie ogłoszeń o pracy oraz badania ankietowego (w latach 2013-2015) pokazały, że w przedsiębiorstwach w Polsce specjaliści ds. RZ pełnią funkcję wewnętrznych konsultantów biznesu silnie zorientowanych na sprawy organizacji, w której pracują. Nie współuczestniczą oni na równych zasadach z innymi menedżerami w procesach podejmowania decyzji, co oznacza, że nie są oni jeszcze partnerami biznesowymi. Z kolei Nowak (m.in. [Nowak 2013; 2014]), rozwijając w Polsce behawioralny nurt badawczy w zakresie controllingu, przedstawiła rodzaje ról zespołowych odgrywanych przez controllerów w świetle teorii ról i wyników własnego badania ankietowego przeprowadzonego wśród 102 praktyków oraz dokonała psychologicznej charakterystyki osób wykonujących zadania controllingu².

Dotychczasowe publikacje bazujące na badaniach empirycznych przeprowadzonych w Polsce prezentowały kwestie statusu specjalistów ds. RZ zazwyczaj w odniesieniu do ogółu podmiotów gospodarczych objętych badaniami. Sprawdzeniem, czy i w jakim stopniu specjaliści ci różnią się pod względem realizowanych zadań, stawianych im wymagań i stosowanych narzędzi RZ oraz czynników wpływających na zmianę ich roli w grupie dużych przedsiębiorstw i należących do sektora MŚP, zajęła się Zarzycka [2016]. W tym celu wykorzystano wyniki badania ankietowego dotyczące 116 przedsiębiorstw (58\% duże, 29\% średnie i 13\% małe). Analiza nie wykazała wielu różnic między praktykami RZ w wymienionych aspektach w przedsiębiorstwach dużych i MŚP. Autorka zidentyfikowała różnicę tylko w jednym z czynników determinujących zmianę roli tych specjalistów (powstanie

\footnotetext{
${ }^{2}$ Ograniczone wymogi objętościowe artykułu uniemożliwią szerszą charakterystykę wyników badań empirycznych zawartych w poszczególnych publikacjach.
} 
nowych narzędzi RZ), a także w obszarze przydatności umiejętności pracy zespołowej oraz komunikatywności i umiejętności interdyscyplinarnych. Te kwestie były bardziej istotne $\mathrm{w}$ grupie firm dużych niż MŚP [Zarzycka 2016, s. 305]. Z kolei Wnuk-Pel i Kawczyńska [2016, s. 99-100] przedstawili m.in. zadania controllerów w firmach produkcyjnych i nieprodukcyjnych w świetle wyników badań ankietowych (130 wypełnionych ankiet), stwierdzając, że zakres tych zadań nie różnił się istotnie w przedsiębiorstwach o różnej wielkości.

$\mathrm{Na}$ podstawie zaprezentowanych ustaleń zasadna jest interpretacja wyników badania ankietowego przeprowadzonego przez autorkę dotyczących zadań i wymaganych kompetencji od specjalistów ds. RZ w przedsiębiorstwach w Polsce w podziale na podmioty małe, średnie i duże. Zgodnie z teorią uwarunkowań sytuacyjnych wielkość przedsiębiorstwa jest uznawana za jedną z podstawowych zmiennych wpływających na zakres zastosowania metod i strukturę systemu RZ podmiotu gospodarczego (por. [Chenhall 2003; Otley 2016]).

\section{Metodyka badania}

W niniejszym artykule jest prezentowana tylko część wyników badania ankietowego przeprowadzonego przez autorkę od marca 2016 r. do stycznia 2017 r. (zob. [Szychta 2019]). Ankieta została skierowana do 480 przedsiębiorstw, których wykaz przygotowano, wybierając podmioty z dwóch list opublikowanych przez dziennik „Rzeczpospolita”, tj. „Listy 500” za 2015 r. i „Rankingu Biznesu TLS 2015”, oraz dodając około 150 przedsiębiorstw z bazy adresowej firm, w których byli zatrudnieni absolwenci studiów podyplomowych rachunkowości zarządczej i controllingu oraz studiów doktoranckich na Wydziale Zarządzania Uniwersytetu Łódzkiego w latach 2014-2016. W przygotowanej bazie na potrzeby badania nie uwzględniono banków $\mathrm{i}$ innych instytucji finansowych. Kwestionariusz ankiety wraz z listem przewodnim dostarczono do przedsiębiorstw tradycyjną pocztą albo autorka uczyniła to osobiście (192) oraz za pośrednictwem poczty elektronicznej (288).

Respondenci byli proszeni o zaznaczenie sugerowanego w kwestionariuszu wariantu odpowiedzi właściwego dla przedsiębiorstwa, w którym pracują, albo sformułowanie odpowiedzi w razie braku wariantu odpowiedniego do ich podmiotu. W przypadkach wymagających oceny danej kwestii ankietowani dokonywali oceny za pomocą pięciostopniowej skali porządkowej. Interpretację wyników badania oparto na przeciętnych ocenach obliczonych z ocen poszczególnych kwestii dokonanych przez respondentów. Wielkości średnie obliczono dla trzech grup podmiotów i ogółu przedsiębiorstw uczestniczących w badaniu.

Respondenci zwrócili 106 ankiet, lecz z powodu niekompletności czterech z nich w analizie danych uwzględniono 102 przedsiębiorstwa. Ankietę wypełnili specjaliści rachunkowości zarządczej lub controllerzy (30\%), księgowi (27\%), członkowie zarządu lub właściciele firm (29\%) oraz menedżerowie niższego szczebla (14\%). 


\section{Wyniki badania}

\subsection{Cechy podmiotów gospodarczych uczestniczących w badaniu ankietowym}

Podział podmiotów gospodarczych, z których pochodzili respondenci, na trzy grupy został dokonany na podstawie jednego kryterium - przeciętnej liczby zatrudnionych. Grupy te stanowią przedsiębiorstwa małe (zatrudniające do 50 osób), średnie (zatrudniające 51-250 pracowników) i duże (zatrudniające ponad 250 osób). Dominującą grupę tworzyły duże przedsiębiorstwa $(47,1 \%)$, a ponad trzy czwarte $(77,5 \%)$ - łącznie średnie i duże podmioty (tabela 1).

Tabela 1. Cechy podmiotów gospodarczych objętych badaniem ankietowym

\begin{tabular}{|c|c|c|c|c|c|}
\hline Wyszczególnienie & Liczba & $\%$ & Wyszczególnienie & Liczba & $\%$ \\
\hline \multicolumn{3}{|l|}{ Wielkość przedsiębiorstw } & \multicolumn{3}{|l|}{ Czas funkcjonowania na rynku } \\
\hline Małe (do 50 osób) & 23 & 22,5 & $1-5$ lat & 15 & 14,7 \\
\hline Średnie (51-250 osób) & 31 & 30,4 & 6-10 lat & 12 & 11,8 \\
\hline Duże (powyżej 250 osób) & 48 & 47,1 & 11-25 lat & 54 & 52,9 \\
\hline Razem & 102 & 100,0 & 26-50 lat & 6 & 5,9 \\
\hline \multirow{3}{*}{\multicolumn{3}{|c|}{  }} & Powyżej 50 lat & 9 & 8,8 \\
\hline & & & Brak danych & 6 & 5,9 \\
\hline & & & Razem & 102 & 100,0 \\
\hline \multicolumn{3}{|l|}{ Forma organizacyjno-prawna } & \multicolumn{3}{|l|}{ Rodzaj działalności } \\
\hline Spółka akcyjna & 21 & 20,6 & $\begin{array}{l}\text { Produkcyjna, produkcyjno- } \\
\text {-usługowa, produkcyjno- } \\
\text {-handlowa }\end{array}$ & 41 & 40,2 \\
\hline Spółka z o.o. & 57 & 55,9 & Usługowa & 42 & 41,2 \\
\hline Inna spółka handlowa & 3 & 3,0 & Handlowa & 11 & 10,8 \\
\hline Spóła cywilna i osoba fizyczna & 5 & 4,9 & Usługowo-handlowa & 8 & 7,8 \\
\hline $\begin{array}{l}\text { Jednostka organizacyjna } \\
\text { nieposiadająca osobowości } \\
\text { prawnej }\end{array}$ & 5 & 4,9 & Razem & 102 & 100,0 \\
\hline Inna forma & 11 & 10,8 & & & \\
\hline Razem & 102 & 100,0 & & & \\
\hline
\end{tabular}

Źródło: opracowanie własne na podstawie wyników badania ankietowego.

W zbiorze badanych znalazły się przedsiębiorstwa o różnych okresach życia rynkowego. Przeważająca większość przedsiębiorstw powstała po 1989 roku, czyli w okresie gospodarki rynkowej w Polsce. Ponad $79 \%$ podmiotów funkcjonowało od jednego roku do 25 lat, 14,7\% firm działało dłużej niż 25 lat, w tym 9 - ponad 50 lat. 
Spółki handlowe stanowiły największą grupę badanych przedsiębiorstw (prawie 80\%). Wśród pozostałych podmiotów znalazły się spółki cywilne, oddziały państwowej jednostki gospodarczej nieposiadającej osobowości prawnej i spółdzielnie. Prawie $60 \%$ badanych podmiotów prowadziło działalność usługową lub handlową, a w około $40 \%$ głównym rodzajem działalności była produkcja, choć część z nich zajmowała się handlem albo świadczeniem usług.

Prawie $\mathrm{w}$ dwóch trzecich przedsiębiorstw $(65,7 \%)$ kapitał własny pochodził w całości ze źródeł krajowych, w 27,5\% - ze źródeł zagranicznych, a w pozostałych przedsiębiorstwach $(6,8 \%)$ działalność finansowano kapitałem krajowym i zagranicznym. Spośród podmiotów objętych badaniem 46,1\% sprzedawało swoje produkty lub towary wyłącznie w Polsce, a 53,1\% czyniło to na rynku krajowym i zagranicznym. Jedno przedsiębiorstwo sprzedawało swoje produkty wyłącznie na rynku zagranicznym.

\subsection{Praktycy w zakresie rachunkowości zarządezej w badanych przedsiębiorstwach}

Zgodnie z wytycznymi zawartymi w Globalnych zasadach rachunkowości zarzączej, aby RZ pomagała organizacjom gospodarczym ,przekształcić liczby w zrozumiałą analizę opisową" i wydobyć ,z natłoku danych najbardziej wartościowe informacje oraz najlepsze dostępne prognozy" na potrzeby podejmowania decyzji biznesowych, powinny one ,zorganizować w swoich strukturach dział rachunkowości zarządczej, który będzie dopełnieniem ich systemu rachunkowości finansowej” [AICPA, CIMA 2015, s. 6].

Z przeprowadzonego badania ankietowego wynika, że w $90 \%$ przedsiębiorstw zadania dotyczące RZ były wykonywane przez specjalnie utworzone działy (tabela 2). Uczestnicy badania z dziesięciu firm, głównie małych, wskazali, że w ich organizacjach nie ma takiego działu, a niezbędne działania w tym zakresie są wykonywane przez kierownika firmy lub księgowego. Wcześniejsze badania empiryczne pokazywały mniejszy odsetek przedsiębiorstw, w których funkcjonowały odrębne działy wykonujące zadania z obszaru RZ (72\% firm w 1999 r. i 74,2\% podmiotów w 2005 r.) [Szychta 2007, s. 237]. Zaobserwowana tendencja wskazuje zatem na wzrost podmiotowy zastosowania RZ wraz z rozwojem gospodarki rynkowej w Polsce.

Zadania dotyczące RZ wykonują pracownicy w działach controllingu, rachunkowości zarządczej lub rachunku kosztów, przy czym w 55\% badanych podmiotów był to dział controllingu. W jednej czwartej badanych, jak stwierdzili respondenci, informacje do celów zarządzania są dostarczane przez osoby pracujące w działach lub sekcjach o innych nazwach, np. biuro analiz ekonomicznych, dział analizy finansowej, dział budżetowania, sekcja analizy i planowania, dział ekonomiczny. Z tego badania, jak i z wcześniejszych ustaleń [Szychta 2007, s. 236-237], wynika, że firmy w Polsce częściej tworzą działy controllingu niż działy RZ. Mając na uwadze organizację rachunkowości ukierunkowanej na potrzeby menedżerów, można stwierdzić, 
że badania te potwierdziły, że wpływ niemieckiej idei Controlling w praktyce w Polsce jest silniejszy niż anglo-amerykańskiej koncepcji management accounting.

Tabela 2. Liczba przedsiębiorstw, w których utworzono działy wykonujące zadania z zakresu RZ

\begin{tabular}{|l|c|c|r|c|}
\hline \multirow{2}{*}{ Nazwa działu } & \multicolumn{3}{c|}{ Przedsiębiorstwa } \\
\cline { 2 - 5 } & małe & średnie & duże & razem \\
\hline Dział controllingu & 3 & 14 & 39 & 56 \\
\hline Dział rachunkowości zarządczej & 1 & 1 & 7 & 9 \\
\hline Dział rachunku kosztów & 0 & 1 & 6 & 7 \\
\hline Inny dział & 11 & 9 & 6 & 26 \\
\hline Brak działu & 8 & 2 & 0 & 10 \\
\hline
\end{tabular}

a) Niektóre przedsiębiorstwa wykazały dwa różne działy.

Źródło: opracowanie własne na podstawie wyników badania ankietowego.

Należy dodać, że w ośmiu spółkach, w których funkcjonuje dział controllingu, wyodrębniono też dział RZ (cztery przypadki) lub sekcję rachunku kosztów (cztery przypadki). Może to dowodzić, że w spółkach, w których jest dział controllingu i RZ, rachunkowość zarządcza i controlling są traktowane jako dwie różne koncepcje, co nie jest właściwe, jak podkreśla np. Sobańska [2010a, s. 97]. Wynika to ze zróżnicowanego traktowania relacji między RZ a controllingiem w Polsce - nawet w środowisku pracowników naukowych rachunkowości (zob. [Szychta, Dobroszek 2017]).

Zadania z zakresu RZ są wykonywane w tych działach przez specjalistów najczęściej nazywanych controllerami albo analitykami, a rzadziej - specjalistami ds. RZ. Jednego specjalistę albo dwóch takich specjalistów zatrudniały małe i średnie przedsiębiorstwa (w około $46 \%$ firm z działem controllingu lub podobnym), 3-5 controllerów pracowało w 30\% firm z takim działem, a 6-9 zatrudnionych było w około 9\% przedsiębiorstw. Respondenci wskazali, że w 17 dużych firmach zatrudniających powyżej 2000 osób pracuje 11 lub więcej controllerów. W trzech przypadkach było to 35,50 , a nawet 485 specjalistów (w 460 oddziałach bardzo dużego podmiotu gospodarczego).

Badanie ankietowe pozwoliło się zorientować, jaka jest hierarchia ważności zadań specjalistów do spraw RZ w przedsiębiorstwach małych, średnich i dużych. Na podstawie dokonanej przez poszczególnych respondentów oceny (według skali porząadkowej od 1 do 5) znaczenia dziesięciu wymienionych w kwestionariuszu ankiety podstawowych zadań tych specjalistów obliczono przeciętne oceny. Są one wykazane w tabeli $3 \mathrm{w}$ kolejności od najwyższej do najniższej, biorąc po uwagę wyniki w kolumnie zatytułowanej „Ogółem”. W każdej grupie przedsiębiorstw duże znaczenie mają dwa zadania: kontrola kosztów i wydatków oraz ustalanie i ocena wyników. Dwa kolejne zadania, tj. przygotowanie i interpretowanie rachunków de- 
cyzyjnych dla zarządu oraz sporządzanie i korygowanie budżetów, uznano także za istotne w podmiotach średnich i dużych. W firmach małych te dwa zadania mają znaczenie odpowiednio średnie i mniej niż średnie. Najmniejsze znaczenie w opinii respondentów mają, niezależnie od wielkości przedsiębiorstwa, zadania polegające na projektowaniu i implementacji nowych systemów informacyjnych oraz wdrażaniu strategii przedsiębiorstwa. Dostarczanie informacji przydatnych kierownikom niższych szczebli w podejmowaniu decyzji nie ma zaś prawie znaczenia w małych firmach, co z pewnością wynika z niewyodrębniania szczebli w tego typu firmach. $\mathrm{W}$ pozostałych dwóch grupach badanych znaczenie tego zadania oceniono na zbliżonym poziomie - jako trochę większe niż średnie.

Tabela 3. Przeciętne oceny znaczenia zadań specjalistów ds. RZ w badanych przedsiębiorstwacha)

\begin{tabular}{|l|c|c|c|c|}
\hline \multirow{2}{*}{ Zadanie } & \multicolumn{4}{c|}{ Przedsiębiorstwa } \\
\cline { 2 - 5 } & małe & średnie & duże & ogółem \\
\hline 1. Kontrola kosztów i wydatków & 4,00 & 4,42 & 4,22 & 4,40 \\
\hline 2. Ustalanie i ocena wyników przedsiębiorstwa & 4,14 & 4,43 & 4,47 & 4,24 \\
\hline $\begin{array}{l}\text { 3. Przygotowanie i interpretowanie rachunków } \\
\text { decyzyjnych dla zarządu }\end{array}$ & 3,21 & 4,23 & 4,17 & 4,03 \\
\hline 4. Sporządzanie i korygowanie budżetów & 2,57 & 4,12 & 4,19 & 3,91 \\
\hline 5. Interpretowanie wyników operacyjnych przedsiębiorstwa & 3,38 & 4,00 & 3,93 & 3,87 \\
\hline 6. Poprawa wyniku finansowego & 3,29 & 3,85 & 3,85 & 3,76 \\
\hline $\begin{array}{l}\text { 7. Dostarczanie informacji wspierających kierowników } \\
\text { niższych szczebli przy podejmowaniu decyzji }\end{array}$ & 1,71 & 3,22 & 3,43 & 3,09 \\
\hline 8. Ocena i kontrola nakładów inwestycyjnych & 2,71 & 2,88 & 3,20 & 3,02 \\
\hline 9. Wdrażanie strategii przedsiębiorstwa & 2,43 & 2,78 & 2,98 & 2,83 \\
\hline $\begin{array}{l}\text { 10. Projektowanie i wdrażanie nowych systemów } \\
\text { informacyjnych w przedsiębiorstwie }\end{array}$ & 2,64 & 2,48 & 2,74 & 2,64 \\
\hline
\end{tabular}

a) Respondenci oceniali znaczenie tych zadań następująco: 1 - brak znaczenia; znaczenie: 2 - małe, 3 - średnie, 4 - duże, 5 - bardzo duże.

Źródło: opracowanie własne.

Prezentowane badanie, podobnie jak wcześniejsze, wykazało, że kontrola kosztów i kontrola finansowa to zadania najwyżej oceniane przez specjalistów RZ/controllerów w Polsce [Szychta 2007, s. 243]. Są one też najczęściej wykonywane przez wskazanych specjalistów, co potwierdziło również badanie ankietowe przeprowadzone przez Zarzycką [2016, s. 255].

W celu udzielenia odpowiedzi na trzecie pytanie sformułowane we wstępie artykułu w tabeli 4 obliczono przeciętną ocenę wpływu dziesięciu czynników na zadania i rolę specjalistów ds. RZ na podstawie oceny dokonanej przez respondentów według skali od 1 do 5. Respondenci uznali wpływ wszystkich tych czynników za 
znaczny albo słaby w każdej grupie badanych firm. Jako główne determinanty uznano postęp $\mathrm{w}$ dziedzinie technologii informacyjnej, wzrost ukierunkowania firmy na potrzeby klientów, wdrożenie nowego informatycznego programu finansowo-księgowego oraz wprowadzenie nowego stylu zarządzania. Rozwój technologii IT od około 15 lat jest wskazywany na pierwszym miejscu przez polskich respondentów jako czynnik oddziałujący na kształtowanie lub zmianę roli specjalistów ds. RZ [Szychta 2007, s. 245; Zarzycka 2016, s. 274]. Nowe technologie produkcji i zmiany właścicielskie okazały się mieć znikomy wpływ na wykonywanie zadań przez controllerów, niezależnie od wielkości przedsiębiorstwa.

Tabela 4. Przeciętne oceny wpływu czynników na kształtowanie roli i zadań praktyków RZ w badanych przedsiębiorstwach ${ }^{\text {a) }}$

\begin{tabular}{|l|c|c|c|c|}
\hline \multirow{2}{*}{ Czynniki } & \multicolumn{4}{c|}{ Przedsiębiorstwa } \\
\cline { 2 - 5 } & małe & średnie & duże & ogółem \\
\hline 1. Rozwój technologii informacyjnej & 2,81 & 2,76 & 2,93 & 2,86 \\
\hline 2. Wzrost orientacji przedsiębiorstwa na potrzeby klientów & 2,29 & 3,00 & 2,89 & 2,83 \\
\hline $\begin{array}{l}\text { 3. Wdrożenie nowego informatycznego programu } \\
\text { finansowo-księgowego }\end{array}$ & 2,53 & 2,42 & 2,93 & 2,70 \\
\hline 4. Wprowadzenie nowego stylu zarządzania & 2,00 & 3,11 & 2,67 & 2,69 \\
\hline 5. Nowe regulacje prawne w zakresie rachunkowości & 2,65 & 2,55 & 2,24 & 2,40 \\
\hline 6. Restrukturyzacja przedsiębiorstwa & 1,63 & 2,50 & 2,57 & 2,37 \\
\hline 7. Procesy globalizacji gospodarki & 2,25 & 1,91 & 2,14 & 2,10 \\
\hline 8. Zalecenia zewnętrznych konsultantów & 2,06 & 1,71 & 2,11 & 2,00 \\
\hline 9. Nowa technologia produkcji & 1,50 & 1,59 & 1,77 & 1,67 \\
\hline 10. Zmiana właściciela przedsiębiorstwa & 1,44 & 1,33 & 1,63 & 1,51 \\
\hline
\end{tabular}

a) Respondenci oceniali wpływ wymienionych czynników, dokonując wyboru spośród następujących możliwości: 1 - brak wpływu, 2 - wpływ słaby, 3 - znaczny, 4 - duży, 5 - bardzo duży.

Źródło: opracowanie własne.

W odpowiedzi na pytanie, czy według respondentów występują różnice w ocenie wiedzy i umiejętności, jakimi powinni charakteryzować się praktycy RZ w przedsiębiorstwach w zależności od ich wielkości, są pomocne obliczenia przeciętnych ocen zestawionych w tabelach 5 i 6 .

W każdej grupie przedsiębiorstw spośród czterech obszarów wiedzy respondenci ocenili najwyżej i na zbliżonym poziomie wiedzę dotyczącą procesów operacyjnych oraz wewnętrznych i zewnętrznych uwarunkowań działalności podmiotu gospodarczego, w którym pracuje specjalista ds. RZ. Dwa następne obszary wiedzy oceniono jako potrzebne w stopniu dużym (także niezależnie od wielkości przedsiębiorstwa). Wiedza z zakresu systemów i programów informatycznych jest potrzebna praktykom RZ w stopniu więcej niż średnim w każdej grupie podmiotów. 
Tabela 5. Znaczenie rodzaju wiedzy specjalistów ds. RZ według oceny respondentówa)

\begin{tabular}{|l|c|c|c|c|}
\hline \multicolumn{1}{|c|}{ Niezbędna wiedza } & \multicolumn{4}{c|}{ Przedsiębiorstwa } \\
\cline { 2 - 5 } & małe & średnie & duże & ogółem \\
\hline $\begin{array}{l}\text { 1. Wiedza o procesach i uwarunkowaniach działalności } \\
\text { podmiotu gospodarczego, w którym jest zatrudniony } \\
\text { specjalista RZ }\end{array}$ & 4,47 & 4,41 & 4,47 & 4,45 \\
\hline $\begin{array}{l}\text { 2. Regulacje prawne i podstawowe zasady rachunkowości } \\
\text { finansowej }\end{array}$ & 4,11 & 4,28 & 4,06 & 4,14 \\
\hline 3. Szeroka wiedza na temat biznesu & 4,11 & 4,07 & 4,13 & 4,11 \\
\hline 4. Wiedza z zakresu systemów informatycznych & 3,63 & 3,45 & 3,85 & 3,68 \\
\hline
\end{tabular}

a) Ankietowani potrzebę posiadania określonego rodzaju wiedzy oceniali następująco: 1 - wiedza zbędna; wiedza potrzebna w stopniu: 2 - małym, 3 - średnim, 4 - dużym, 5 - bardzo dużym.

Źródło: opracowanie własne.

Tabela 6. Znaczenie umiejętności i postaw specjalistów ds. RZ według oceny respondentówa)

\begin{tabular}{|l|c|c|c|c|}
\hline \multirow{2}{*}{ Umiejętności } & \multicolumn{4}{c|}{ Przedsiębiorstwa } \\
\cline { 2 - 5 } & małe & średnie & duże & ogółem \\
\hline 1. Analizowanie i interpretowanie & 4,42 & 4,47 & 4,77 & 4,61 \\
\hline 2. Kojarzenie danych finansowych z niefinansowymi & 4,47 & 4,30 & 4,46 & 4,41 \\
\hline 3. Myślenie w kategoriach strategicznych & 4,58 & 3,86 & 4,06 & 4,11 \\
\hline 4. Rozpoznawanie i ocena ryzyka & 4,26 & 4,10 & 4,15 & 4,16 \\
\hline 5. Szybkie przystosowywanie się do zmian & 4,28 & 3,93 & 4,19 & 4,13 \\
\hline 6. Werbalne komunikowanie się & 3,37 & 4,07 & 4,04 & 3,91 \\
\hline 7. Latwość podejmowania decyzji & 3,68 & 3,61 & 3,81 & 3,72 \\
\hline 8. Praca zespołowa & 3,50 & 3,90 & 4,02 & 3,88 \\
\hline 9. Etyczne zachowanie & 4,00 & 3,96 & 3,98 & 3,98 \\
\hline
\end{tabular}

a) Respondenci dokonywali oceny według skali: 1 - umiejętność zbędna; umiejętność potrzebna w stopniu: 2 - małym, 3 - średnim, 4 - dużym, 5 - bardzo dużym.

Źródło: opracowanie własne.

Umiejętności analityczne i interpretacyjne oraz kojarzenie danych finansowych $\mathrm{z}$ niefinansowymi uznano za potrzebne w stopniu powyżej dobrego w podmiotach zarówno małych, średnich, jak i dużych. Trzy następne umiejętności (nr 3-5) wyszczególnione w tabeli 6 zostały ocenione jako wymagane w stopniu dobrym lub nieco wyższym niż dobrym we wszystkich grupach przedsiębiorstw, ale przeciętnie najwyżej oceniono je w małych firmach, co jest niespodziewane, ale jednocześnie stanowi dobrą prognozę. Może to świadczyć o tym, że w małych podmiotach pracownik wykonujący zadania z zakresu RZ postrzega swoje obowiązki bardziej 
w powiązaniu z całym przedsiębiorstwem, jego strategią i ryzykiem działalności niż w większych jednostkach, w których jego zadania jako jednego spośród pracowników działu mogą mieć charakter cząstkowy. $Z$ kolei umiejętność pracy zespołowej została oceniona najniżej $(3,50) \mathrm{w}$ małych i najwyżej $(4,02) \mathrm{w}$ dużych podmiotach. Ta ocena jest zgodna z wynikiem uzyskanym w badaniu przez Zarzycką [2016, s. 284 i 288], w którym respondenci przypisali większe znaczenie pracy zespołowej controllera w firmach dużych niż w MŚP. Etyczne zachowanie uzyskało ocenę wymaganą w stopniu dużym w każdej grupie przedsiębiorstw i nieco wyższą od przeciętnej $(3,69)$, odnotowanej w badaniach przeprowadzonych ponad dekadę wcześniej [Szychta 2007, s. 246].

\section{Zakończenie}

Wyników prezentowanego badania ankietowego nie można uogólniać na wszystkie przedsiębiorstwa w Polsce ze względu na brak losowości próby. Badanie to pozwoliło na zidentyfikowanie i ocenę ważności zadań specjalistów ds. RZ, określenie znaczenia czynników determinujących wykonywanie tych zadań oraz znaczenia wymogów kompetencyjnych stawianych tym specjalistom w małych, średnich i dużych przedsiębiorstwach w Polsce, które wzięły udział w badaniu w 2016 r. Uzyskane wyniki poszerzają jednak dotychczasowe informacje o podobieństwie albo zróżnicowaniu rozpatrywanych kwestii w zależności od wielkości przedsiębiorstwa w trzecim dziesięcioleciu rozwoju gospodarki rynkowej w Polsce po transformacji systemu społeczno-gospodarczego, które znano z wcześniejszych badań empirycznych przeprowadzonych przez Zarzycką [2016] oraz Wnuka-Pel i Kawczyńską [2016].

$\mathrm{Z}$ badania wykonanego przez autora niniejszego artykułu wynika, że zadania dotyczące RZ w dużych i średnich firmach są wykonywane najczęściej przez działy controllingu, a w małych - przez działy, jeśli je wyodrębniono, o innych nazwach. Respondenci, bez względu na wielkość przedsiębiorstwa, przywiązują największą wagę do dwóch zadań specjalistów RZ: kontroli kosztów i wydatków oraz pomiaru wyników. Zadania polegające na projektowaniu i implementacji systemów RZ oraz działania związane $\mathrm{z}$ wdrażaniem strategii przedsiębiorstwa uznają oni za mające niewielkie znaczenie $w$ firmach niezależnie od ich wielkości. Badanie potwierdziło, że rozwój technologii IT jest nadal wskazywany przez polskich respondentów na pierwszym miejscu jako czynnik oddziałujący na kształtowanie lub zmianę roli specjalistów ds. RZ. Respondenci uznali jednak wpływ tego czynnika za znaczny, a nie za duży bądź bardzo duży. Wpływ pozostałych czynników, np. wzrost orientacji na potrzeby klientów albo wprowadzenie nowego stylu zarządzania, oceniono także jako znaczny albo słaby w każdej grupie badanych firm. Stosunkowo wysoko i podobnie oceniono obszary wiedzy wymagane od praktyków RZ w trzech grupach przedsiębiorstw. Spośród umiejętności i postaw, którymi powinni charakteryzować się ci praktycy, mniejsze znaczenie nadaje się umiejętności pracy zespołowej w małych firmach. 
Badanie ankietowe ujawniło zatem - podobnie jak badanie przprowadzone przez Zarzycką [2016] - nieliczne różnice w sprawdzanych aspektach dotyczących specjalistów RZ w przedsiębiorstwach małych, średnich i dużych. Szczegółowa analiza wyników w powiązaniu z dwoma głównymi modelami roli specjalistów ds. RZ prowadzi ponadto do wniosku, że ci specjaliści w Polsce odgrywają rolę bardziej zbliżoną do tradycyjnej (controllera dostarczającego informacje kierownikom do podejmowania decyzji, ustalającego wyniki działalności, kontrolującego koszty i wydatki) niż do roli finansowego partnera biznesowego, czyli profesjonalisty w dziedzinie RZ partnerującego menedżerom w formułowaniu i realizacji strategii podmiotu gospodarczego.

\section{Literatura}

AICPA, CIMA, 2015, Globalne Zasady Rachunkowości Zarzadczej@, https://www.cgma.org/content/dam/cgma/resources/reports/downloadabledocuments/polish-full-document-gmaps.pdf, dostęp 12.04.2018.

Anderson S.W., Lanen W.N., 1999, Economic transition, strategy and the evolution of management accounting practices: The case of India, Accounting, Organizations and Society, vol. 24 (5-6), s. 379-412.

Burns J., Ezzamel M., Scapens R.W., 2003, The Challenge of Management Accounting Change, Behavioral and Cultural Aspects of Change Management, CIMA Publishing, Elsevier, AmsterdamBoston-London.

Burns J., Vaivio J., 2001, Management accounting change, Management Accounting Research, vol. 12, no. 4 , s. 389-402.

Byrne S., Pierce B., 2007, Towards a more comprehensive understanding of the roles of management accountants, European Accounting Review, vol. 16, no. 3, s. 469-498.

Chenhall R.H., 2003, Management control systems design within its organizational context: Findings from contingency-based research and directions for the future, Accounting, Organizations and Society, vol. 28 (2-3), s. 127-168.

CIMA, 2009, Improving Decision Making in Organisations. The Opportunity to Reinvent Finance Business Partners, London.

Dynowska J., 2011, Zadania controllera $w$ przedsiębiorstwach $w$ świetle badań ankietowych, Prace Naukowe Uniwersytetu Ekonomicznego we Wrocławiu, nr 181, s. 147-155.

Goliszewski J., 2002, Rozwój controllingu w Polsce na podstawie ogłoszeń o pracę, Controlling i Rachunkowość Zarządcza, nr 6, s. 21-26.

Grandlund M., Lukka K., 1998a, It's a small world of management accounting practices, Journal of Management Accounting Research, vol. 10, s. 151-179.

Grandlund M., Lukka K., 1998b, Towards increasing business orientation: Finish management accountants in changing cultural context, Management Accounting Research, 9, s. 185-211.

Hopper T., Tsamenyi M., Uddin S., Wickramasinghe D., 2009, Management accounting research in less developed countries: What is known and needs knowing, Accounting, Auditing \& Accountability Journal, vol. 2 (3), s. 469-514.

https://www.cimaglobal.com/Documents/Thought_leadership_docs/cid_execrep_finance_business_ partners_Jul09.pdf, dostęp 12.04.2019.

IFAC, 1998, Management Accounting Concepts. International Management Accounting Practice Statement, Financial and Management Accounting Committee, International Federation of Accountants, New York. 
IMA, 2008, Statements on Management Accounting, Definition of Management Accounting, Institute of Management Accountants, Montvale.

Kaplan R.S., 1995, New roles for management accountants, Journal of Cost Management, vol. 9, no. 3, s. 6-13.

Keating P.J., Ansari S., 1997, The Organizational Role of Management Accountants, Version 1.0, The McGraw-Hill Companies, Inc., USA.

Král B., Mikołajewicz G., Nowicki J., Šoljakova L., 2017, Professional competences of controllers: The case of Poland, European Financial and Accounting Journal, vol. 12, no. 2, s. 17-40.

Lambert C., Sponem S., 2012, Roles, authority and involvement of the management accounting function: A multiple case-study perspective, European Accounting Review, vol. 21, issue 3, s. 565-589.

Ngoc Phi Anh D., Nguyen D., Mia L., 2011, Western management accounting practices in Vietnamese enterprises. Adoption and perceived benefits, Pacific Accounting Review, vol. 23, no. 2, s. $142-$ -164, https://doi.org/10.1108/01140581111163971.

Nowak M., 2013, Praca w controllingu a przyjmowane role grupowe. Analiza wyników badań empirycznych, Prace Naukowe Uniwersytetu Ekonomicznego we Wrocławiu, nr 289, s. 438-448.

Nowak M., 2014, Psychologiczna charakterystyka osób realizujacych zadania controllingu, [w:] H. Lelusz, R. Burchrad (red.), Wspótczesne problemy rachunkowości w teorii i praktyce, Wydawnictwo Uniwersytetu Warmińsko-Olsztyńskiego, Olsztyn, s. 239-251.

O'Connor N., Chow C., Wu A., 2004, The adoption of Western Management accounting/controls in China's stated enterprises during economic transition, Accounting, Organizations and Society, no. 29(3/4), s. 349-375.

Otley D., 2016, The contingency theory of management accounting and control: 1980-2014, Management Accounting Research, vol. 31, s. 45-62.

Pietrzak Ż., Wnuk-Pel T., 2015, The Roles and Qualities of Management Accountants in Organizations - Evidence from the Field, 20th International Scientific Conference Economic and Management 2015, Procedia - Social and Behavioral Sciences, www.science.direct.com, dostęp: kwiecień 2019.

Rieg R., 2018, Tasks, interaction and role perception of management accountants: Evidence from Germany, Journal of Management Control, vol. 29 (2), s. 183-220.

Rozporządzenie Ministra Pracy i Polityki Społecznej z dnia 7 sierpnia 2014 r. w sprawie klasyfikacji zawodów i specjalności na potrzeby rynku pracy oraz zakresu jej stosowania, Dz.U.R.P. z dnia 25 stycznia 2018 r., poz. 227, Obwieszczenie Ministra Rodziny, Pracy i Polityki Społecznej z dnia 28 grudnia $2017 \mathrm{r}$.

Scapens R.W., Ezzamel M., Burns J., Baldvinsdottir G., 2003, The Future Direction of UK Management Accounting Practice, CIMA Publishing, Elsevier, Amsterdam-Boston-London.

Selto F.H., Widener S.K., 2004, New directions in management accounting research: Insights from practice, Advances in Management Accounting, vol. 12, s. 1-35.

Sobańska I., 2010a, Rachunkowość zarządcza, [w:] I. Sobańska (red.), Rachunkowość zarzadcza. Podejście operacyjne i strategiczne, Wydawnictwo C.H. Beck, Warszawa, s. 73-106.

Sobańska I., 2010b, Rozwój rachunkowość zarządczej w Polsce po 1990 r., [w:] Sobańska I. (red.), Rachunkowość zarzadcza. Podejście operacyjne i strategiczne, Wydawnictwo C.H. Beck, Warszawa, s. 616-640.

Sobańska I., Kabalski P., 2014, Partner biznesowy - nowa rola specjalisty rachunkowości zarządczej, Przegląd Organizacji, nr 7, s. 19-25.

Sobańska I., Wnuk T., 2000, Zmiany w praktyce rachunkowości na przełomie XX i XXI wieku, Zeszyty Teoretyczne Rady Naukowej, SKwP, nr 56, s. 215-221.

Szychta A., 2005, Rola współczesnych specjalistów rachunkowości zarządczej w świetle ewolucji jej zakresu i metod, Zeszyty Teoretyczne Rachunkowości, nr 25 (81), s. 80-107.

Szychta A., 2007, Etapy ewolucji i kierunki integracji metod rachunkowości zarządczej, Wydawnictwo Uniwersytetu Łódzkiego, Łódź. 
Szychta A., 2011, Rachunkowość zarządcza jako działalność zawodowa w kontekście doświadczeń zagranicznych, Zeszyty Teoretyczne Rachunkowości, nr 62 (118), s. 289-312.

Szychta A., 2014, Wybrane organizacyjne i etyczne aspekty praktyki rachunkowości zarzadczej, [w:] A. Jaruga, P. Kabalski, A. Szychta, Rachunkowość zarzadcza, wyd. II, rozszerzone i zaktualizowane, Wolters Kluwer Polska, Warszawa, s. 791-813.

Szychta A., 2018, Management accounting practices in developing countries since the 1990s: The case of Poland, Zeszyty Teoretyczne Rachunkowości, nr 99 (155), s. 119-148.

Szychta A., 2019, Wielkość przedsiębiorstwa jako determinanta praktyki rachunkowości zarządczej, Zeszyty Teoretyczne Rachunkowości, nr 103 (159), s. 183-202.

Szychta A., Dobroszek J., 2017, Academic aspects of management accounting and controlling in Poland since the 1990s, Zeszyty Teoretyczne Rachunkowości, nr 93 (149), s. 175-209.

Wnuk-Pel T., Kawczyńska M., 2016, The Role and Functions of Controllers in Organization Management, Wydawnictwo Uniwersytetu Łódzkiego, Łódź.

Zarzycka E., 2012, Management accountant's role and functions in the ERP environment - focus on internal reporting and performance measurement, Comparative Economic Research. Central and Eastern Europe, vol. 15, no. 2, s. 47-64.

Zarzycka E., 2016, Koncepcje i tendencje rozwoju zawodu specjalisty rachunkowości zarządczej. Wymiar krajowy i międzynarodowy, Wydawnictwo Uniwersytetu Łódzkiego, Łódź.

Zarzycka E., 2017, The role of management accountant in enterprises operating in Poland, Zeszyty Teoretyczne Rachunkowości, nr 93 (149), s. 235-252. 